University of South Carolina

Scholar Commons

9-1-1992

\title{
Nuclear DNA Content Variation Within the Rosaceae
}

\author{
E. E. Dickson \\ Cornell University \\ K. Arumuganathan \\ Cornell University \\ Stephen Kresovich \\ University of South Carolina - Columbia, sk@sc.edu \\ J. J. Doyle \\ Cornell University
}

Follow this and additional works at: https://scholarcommons.sc.edu/biol_facpub

Part of the Biology Commons

\section{Publication Info \\ Published in American Journal of Botany, ed. Judy Jernstedt, Volume 79, Issue 9, 1992, pages 1081-1086. (C) American Journal of Botany 1992, Botanical Society of America.}

This Article is brought to you by the Biological Sciences, Department of at Scholar Commons. It has been accepted for inclusion in Faculty Publications by an authorized administrator of Scholar Commons. For more information, please contact digres@mailbox.sc.edu. 


\title{
NUCLEAR DNA CONTENT VARIATION WITHIN THE ROSACEAE ${ }^{1}$
}

\author{
E. E. Dickson, ${ }^{2,5}$ K. Arumuganathan, ${ }^{3}$ \\ S. KRESOVICH, ${ }^{4}$ AND J. J. DOYlE ${ }^{2}$ \\ ${ }^{2} \mathrm{~L}$. H. Bailey Hortorium and ${ }^{3}$ Department of Plant Breeding and Biometry, \\ Cornell University, Ithaca, New York 14853-4301; and \\ ${ }^{4}$ USDA-ARS Plant Genetic Resources Unit, Cornell University, Geneva, New York 14456-0462
}

\begin{abstract}
Nuclear DNA content has been estimated using flow cytometry for 17 species and eight cultivars of Malus and for 44 species of 29 other genera within the Rosaceae. Compared to other angiosperms, diploid genome sizes vary little within the family Rosaceae and within the genus Malus. C-values of genera within the subfamilies Spiraeoideae and Rosoideae are among the smallest of flowering plants thus far reported. In general, the Maloideae have the largest diploid genomes of the family, consistent with their higher chromosome numbers and presumed polyploid origin.
\end{abstract}

The Rosaceae, including such economically important plants as almond, apple, strawberry, and rose, is considered a natural group held together by similarities in floral structures. The four subfamilies are defined by fruit type (Robertson, 1974), and each includes polyploid series with fairly consistent chromosome base numbers: Spiraeoideae $(x=9)$; Amygdaloideae $(x=8)$; Rosoideae $(x=7,8$, and 9); and Maloideae $(x=17)$ (Sax, 1931, 1932). The subfamily Maloideae, with its relatively high base chromosome number, has been hypothesized to be either of autopolyploid (Darlington and Moffett, 1930) or allopolyploid origin (Sax, 1931, 1932; Stebbins, 1950).

Although numerous chromosome numbers have been reported for Rosaceae, the amount of DNA per nucleus (C-value) has been reported for only 14 species of the family (Bennett and Smith, 1976, 1991; Bennett, Smith, and Heslop-Harrison, 1982; Arumuganathan and Earle, 1991b). Apart from the utility of genome size data in ongoing molecular studies in this important plant family, the amount and distribution of nuclear DNA content variation among related taxa may give insights into genomic evolution that underlies or parallels speciation (Raina and Narayan, 1984; Ohri and Khoshoo, 1986; Price, 1988).

In this study, flow cytometry was used to estimate nuclear DNA contents of 28 genera from each of the four Rosaceae subfamilies. Compared to Feulgen densitometry or reassociation kinetics, flow cytometry is a rapid and reliable method for estimating $\mathrm{C}$-values in plants (Galbraith et al., 1983; De Laat, Gohde, and Vogelzang, 1987; Rayburn et al., 1989; Rayburn, 1990; Michaelson et al., 1991a). We here report low levels of nuclear DNA variation within the Rosaceae and find that Spiraeoideae $\mathrm{C}$-values are among the smallest of angiosperms. Relatively large C-values of Maloideae support the polyploid origin of the subfamily.

\footnotetext{
${ }^{1}$ Received for publication 25 November 1991; revision accepted 27 April 1992.

The authors thank Steven Spongberg of the Arnold Arboretum for helping in the collection of leaf samples; Martha Rangel-Lugo for providing chicken blood; and Kathy Anderson and Jim Slattery for assisting in the operation of the flow cytometer.

${ }^{5}$ Author for correspondence.
}

\section{MATERIALS AND METHODS}

Leaf material of rosaceous taxa was collected from several sources (Table 1). Voucher specimens are deposited at the L. H. Bailey Hortorium (BH). Chromosome counts, where available, were gathered from the literature (Table 2).

For the determination of nuclear DNA content, suspensions of intact nuclei were prepared from young leaves by chopping (Galbraith et al., 1983) according to the procedure of Arumuganathan and Earle (1991a) and stained with propidium iodide. The isolation procedure was further modified for some members of the subfamily Rosoideae by the addition of $1 \%$ polyvinyl pyrrolidone (PVP40 ) to the initial isolation solution, without the addition of propidium iodide. The modified procedure increased the number of intact nuclei isolated. The mean fluorescence intensity, frequency, standard deviation, and coefficient of variation of the propidium iodide-stained nuclei at $488 \mathrm{~nm}$ were recorded with an EPICS PROFILE flow cytometer (Coulter Electronics, Hialeah, FL). Chicken erythrocytes (2.33 pg DNA/2C; Galbraith et al., 1983) were included with our samples as internal standards (Fig. 1).

The mean 2C-value of each sample was determined by multiplying the ratio of the fluorescence means of the sample nuclei and chicken erythrocytes by the amount of DNA per chicken erythrocyte $(2.33 \mathrm{pg})$. The standard deviation for the mean $2 \mathrm{C}$-value of each sample was calculated by taking into account the variances of the fluorescence from both the sample and the internal standard (W. Lamboy, personal communication):

$$
\begin{gathered}
\sigma^{2}(\mathrm{samp} / \mathrm{crbc})=\sigma^{2}(\mathrm{samp}) / \mathrm{M}(\mathrm{crbc})^{2} \\
+\left[\sigma^{2}(\mathrm{crbc}) \times \mathrm{M}(\mathrm{samp})^{2}\right] / \mathrm{M}(\mathrm{crbc})^{4} \\
\text { Sample C-value standard deviation } \\
=\sigma(\mathrm{samp} / \mathrm{crbc}) \times 2.33
\end{gathered}
$$

where

$$
\sigma^{2}=\text { fluorescence variance }
$$$$
\mathrm{M}=\text { fluorescence mean }
$$$$
\text { samp }=\text { sample nuclei }
$$$$
\text { crbc }=\text { chicken erythrocytes }
$$

Our standard deviations are up to twice as large as for 
those in which we assumed no variance for the standard. Previous reports of C-value standard deviations: 1) assume the standard is constant without variance (Rothfels et al., 1966; Narayan, 1982; Price et al., 1983; Goldblatt, Walbot, and Zimmer, 1984; Laurie and Bennett, 1985; Sims and Price, 1985); 2) use a standard assuming a constant mean and a constant standard deviation (Galbraith et al., 1983); or 3) give standard deviations around the mean fluorescence or mean density of the sample in arbitrary units (Chooi, 1971; Price and Bachmann, 1975; Rayburn et al., 1989; Rayburn, 1990; McMurphy and Rayburn, 1991).

\section{RESULTS AND DISCUSSION}

The genomic DNA contents of 44 rosaceous plants (29 genera), estimated from the mean fluorescence values of 500-2,000 nuclei per sample, are listed in Table 2 . The coefficients of variation were less than $5 \%$ for all reported samples. Previously obtained 2C-values of Rosaceae are included in Table 2: six estimated by Feulgen microdensitometry (Bennett and Smith, 1976, 1991; Bennett, Smith, and Heslop-Harrison, 1982) and eight others obtained by flow cytometry recently reported by one of us (Arugumanathan and Earle, 1991b). The values obtained by Feulgen densitometry agree closely with the flow cytometry values of other species within the same subfamily.

Polyploid series - The 2C-values of Malus $\times$ domestica and Prunus species correlate with their chromosome counts. Malus $\times$ domestica accessions with chromosome numbers of $2 x, 3 x$, and $4 x$ have 2C-values (standard deviation) of $1.55(0.21), 2.51(0.20)$, and $2.86(0.43) \mathrm{pg}$, respectively, deviations from a perfect numerical series well within the variation found within apple (Table 3 ). The $2 \mathrm{C}$ value of the diploid sweet cherry Prunus avium $(0.67 \mathrm{pg})$ is approximately half that of the tetraploid hybrid cherry Prunus $\times$ sp. ' $4 \mathrm{X}$ ' $(1.36 \mathrm{pg})$.

In contrast, the nuclear DNA contents of Spiraea pubescens and $S$. nipponica, reportedly diploids, are two and four times larger than the diploid genome of $S$. chinensis (Table 2). Because polyploidy is reported in this genus, it is reasonable to conclude that our accessions of $S$. pubescens and $S$. nipponica are polyploids. Chromosome counts are necessary, however, to confirm polyploidy for these Spiraea accessions. If their chromosome numbers are diploid, the $2 \mathrm{C}$-value variation among diploid Spiraea species would be remarkably large, with nearly as much variation as found within the Rosaceae as a whole.

Diploid Rosaceae C-values are low among angiosperms -Arabidopsis thaliana (L.) Heynh. (Brassicaceae) is widely known for its very small nuclear genome, with estimates of its $2 \mathrm{C}$-value varying from $0.15 \mathrm{pg}$ (Leutwiler, Hough-Evans, and Meyerowitz, 1984), 0.30 pg (Arumuganathan and Earle, 1991a), to 0.4 pg (Bennett and Smith, 1991) determined by reassociation kinetics, flow cytometry, and Feulgen microdensitometry, respectively (discussed by Arumuganathan and Earle, 1991a). The discrepancy among these reported $2 \mathrm{C}$-values may be due to the multiple ploidy levels in Arabidopsis thaliana (Fig. 1) (Arumuganathan and Earle, $1991 \mathrm{a}$; Galbraith, Harkins, and Knapp, 1991). Recently, an even smaller nuclear
TABLE 1. Original sources and vouchers of plants used in this study. $A A=$ Arnold Arboretum; $C U=$ Cornell University; $N Y$ $S A E S=$ New York State Agricultural Experiment Station, Geneva, New York

Spiraeoideae:

Exochorda giraldii, AA 1503-52A, EED 872. Neillia simensis, AA 144-81, EED 875. Physocarpus bracteatus, AA 1235-85, EED 856; P. opulifolius, AA 1279-82-A, EED 857. Spiraea chinensis, AA 22383, EED 855; S. crenata, AA 1230-85, EED 859; $S$. pubescens, AA 541-83, EED 853; $S$. nipponica, CU, EED 900; S. sargentiana, AA 1233-85, EED 854; $S$. wilsonii, AA 953-85-A, EED 852. Stephanandra incisa, CU, EED 902.

Amygdaloideae:

Osmaronia cerasiformis, AA 274-85, EED 879. Prinsepia uniflora, AA 7188-A, EED 848. Prunus persica "Red Haven," NYSAES, no voucher; $P$. serotina, NYSAES, EED $879 ; P$. subhirtella, CU, EED 903.

Rosoideae:

Dryas octopetala, CU, EED 892. Duchesnea indica, Geneva, NY, EED 898. Neviusia alabamensis, AA 1809-71, EED 873. Potentilla fructicosa, CU, EED 899. Rhodotypus scandens, AA 680-79, EED 851. Rosa multiflora, Geneva, NY, EED 897. Rubus odoratus, CU, EED 896.

Maloideae:

Amelanchier sp., NYSAES, EED 876. Aronia arbutifolia, AA 190581, EED 870. Chaenomeles speciosa, NYSAES, EED 881. Cotoneaster melanocarpa, Geneva, NY, EED 882. Crataegus crus-galli, Geneva, NY, EED 883. Cydonia oblonga, NYSAES, EED 877. Eriobotrya japonica, CU, no voucher. Malus spp., NYSAES. Mespilus germanica, NYSAES, EED 878. Photinea parvifolia, AA 577-76, EED 867. Pyracantha coccinea, CU, EED 901; P. sp. "Royal," AA 194-49-A, EED 869. Pyrus calleryana, CU, EED 895. Sorbus alnifolia, CU, EED $880 ;$ S. americana, NYSAES, EED 894.

genome was reported for Cardamine amara L. $(0.11 \mathrm{pg} /$ 2C) (Bennett and Smith, 1991), another member of the Brassicaceae.

Other small C-values occur within the Rosaceae. Rosa wichuraiana Crepin (Rosoideae) has a genome size of 0.2 $\mathrm{pg} / 2 \mathrm{C}$ (Bennett and Smith, 1991). Within the Spiraeoideae, several woody species of Spiraea and Physocarpus gave fluorescence peaks between 0.42 and $0.46 \mathrm{pg} / 2 \mathrm{C}$ (Table 2) (Figs. 2, 3). Outside the Brassicaceae and Rosaceae, a genome smaller than these Spiraeoideae has only been reported for Aesculus hippocastanum L. $(0.3 \mathrm{pg} / 2 \mathrm{C}$, Feulgen microdensitometry) (Bennett, Smith, and HeslopHarrison, 1982). However, we were unable to substantiate this value using leaf tissue sampled from an $A$. hippocastanum on the Cornell campus $(1.04 \mathrm{pg} / 2 \mathrm{C}$; SD 0.05; flow cytometry).

The subfamily Amygdaloideae also has relatively small 2C-values (Table 2); however, Prunus diploid genomes, with $2 \mathrm{C}$ values between 0.54 and $0.66 \mathrm{pg}$, are comparable with the genomes of other diploid angiosperms with small $2 \mathrm{C}$-values, e.g., Urtica urens L. (Urticaceae) $(0.6 \mathrm{pg} / 2 \mathrm{C})$ and Lablab niger Medik. (Fabaceae) $(0.7 \mathrm{pg} / 2 \mathrm{C}$ ) (Bennett and Smith, 1976).

Rosaceae diploid $2 C$-value variation-A range in DNA content among diploid species of nearly eightfold was detected among 28 genera of the four Rosaceae subfamilies (Fig. 4). The range of $\mathrm{C}$-values reported for a family is meaningful only if sampling of taxa is extensive. Al- 
TABLE 2. Mean 2C-values, standard deviations (SD), and ploidy levels of Rosaceae species with citations of source and ploidy reference

\begin{tabular}{|c|c|c|c|c|c|}
\hline & $2 \mathrm{C}(\mathrm{pg})$ & SD & Source $^{\mathrm{s}}$ & Ploidy & Ploidy ref \\
\hline \multicolumn{6}{|l|}{ Spiraeoideae $x=9$} \\
\hline Physocarpus opulifolius (L.) Maxim. & 0.42 & 0.09 & 1 & $2 x$ & 6 \\
\hline Spiraea chinensis Maxim. & 0.42 & 0.11 & 1 & & \\
\hline Physocarpus bracteatus (Rydb.) Rehd. & 0.43 & 0.07 & 1 & & \\
\hline Spiraea crenata L. & 0.46 & 0.10 & 1 & & \\
\hline Stephanandra incisa (Thunb.) Zabel & 0.53 & 0.06 & 1 & & \\
\hline Neillia simensis D. Oliver & 0.54 & 0.08 & 1 & $2 x$ & 3 \\
\hline Spiraea pubescens Turcz. & 0.94 & 0.11 & 1 & $2 x$ & 7 \\
\hline Exochorda giraldii Hesse. $x=8$ & 1.11 & 0.19 & 1 & $2 x$ & 7 \\
\hline Spiraea wilsonii Duthie & 1.59 & 0.15 & 1 & & \\
\hline Spiraea nipponica Maxim. & 1.75 & 0.13 & 1 & $2 x$ & 7 \\
\hline Spiraea sargentiana Rehd. & 1.84 & 0.11 & 1 & & \\
\hline \multicolumn{6}{|l|}{ Amygdaloideae $x=8$} \\
\hline Prunus persica (L.) Batch. "Madison" & 0.54 & 0.05 & 3 & $2 x$ & 7 \\
\hline Prunus persica (L.) Batch. "Red Haven" & 0.55 & 0.06 & 1 & $2 x$ & 7 \\
\hline Prunus armenaica L. "Sundrop" & 0.60 & 0.06 & 3 & $2 x$ & 7 \\
\hline Prunus subhirtella Miq. & 0.60 & 0.09 & 1 & $2 x$ & 7 \\
\hline Prunus avium (L.) L. "Van" & 0.67 & 0.06 & 3 & $2 x$ & 5 \\
\hline Osmaronia cerasiformis $x=6$ & 0.98 & 0.11 & 1 & $2 x$ & 6 \\
\hline \multicolumn{6}{|l|}{ (Torr. \& Gray ex Hook. \& Arn.) Greene } \\
\hline Prunus serotina J.F. Ehrh. & 1.00 & 0.13 & 1 & $4 x ; 5 x ; 6 x$ & 3 \\
\hline Prunus $\times$ spp. " $4 \mathrm{X} "$ & 1.36 & 0.12 & 3 & $4 x$ & \\
\hline Prunus cerasus L. "Montmorency" & 1.42 & 0.08 & 3 & $4 x$ & 2 \\
\hline Prunus $\times$ spp. "Standley" & 1.83 & 0.07 & 3 & $6 x$ & \\
\hline Prinsepia uniflora Batal. & 3.09 & 0.28 & 1 & $4 x$ & 7 \\
\hline \multicolumn{6}{|l|}{ Rosoideae } \\
\hline Rosa wichuraiana Crepin $x=7$ & 0.2 & & 2 & $2 x$ & \\
\hline Rubus idaeus L. $x=7$ & 0.58 & 0.10 & 3 & $2 x ; 4 x$ & 1 \\
\hline Rosa blanda Aiton $x=7$ & 0.6 & & 2 & $3 x$ & \\
\hline Acaena magellanica (Lam.) Vahl. $x=7$ & 0.6 & & 4 & $6 x$ & 2 \\
\hline Potentilla fructicosa $\mathrm{L}$. & 0.80 & 0.70 & 1 & $2 x ; 4 x ; 6 x$ & 8 \\
\hline Rhodotypus scandens (Thunb.) Mak. $x=9$ & 0.74 & 0.10 & 1 & $2 x$ & 7 \\
\hline Rubus odoratus L. $x=7$ & 0.76 & 0.22 & 1 & $2 x$ & 8 \\
\hline Neviusia alabamensis A. Gray $x=9$ & 1.02 & 0.11 & 1 & $2 x$ & 6 \\
\hline Sanguisorba minor Scop. $x=7$ & 1.1 & & 2 & $4 x$ & \\
\hline Aphanes arvensis L. $x=8$ & 1.1 & & 5 & $6 x$ & 7 \\
\hline Dryas octopetala L. $x=9$ & 1.16 & 0.25 & 1 & $2 x$ & 1 \\
\hline Rosa acicularis Lindley $x=7$ & 1.3 & & 2 & $6 x$ & \\
\hline Rosa multiflora Thunb. ex J. Murr. $x=7$ & 1.65 & 0.11 & 1 & $2 x ; 4 x$ & 1 \\
\hline Duchesnea indica (Andr.) Focke $x=7$ & 3.00 & 0.14 & 1 & $6 x ; 12 x$ & 8 \\
\hline \multicolumn{6}{|l|}{ Maloideae $x=17$} \\
\hline Pyracantha "Royal" & 0.99 & 0.16 & 1 & & \\
\hline Pyrus communis L. "Bartlett" & 1.11 & 0.06 & 3 & $2 x$ & 7 \\
\hline Chaenomeles speciosa (Sweet) Nakai & 1.20 & 0.16 & 1 & $2 x$ & 7 \\
\hline Pyrus calleryana Decne. & 1.26 & 0.29 & 1 & $2 x$ & 7 \\
\hline Amelanchier sp. & 1.31 & 0.25 & 1 & & \\
\hline Sorbus alnifolia (Siebold \& Zucc.) Koch & 1.36 & 0.32 & 1 & $2 x$ & 7 \\
\hline Sorbus americana Marsh & 1.30 & 0.37 & 1 & $2 x$ & 7 \\
\hline Pyracantha coccinea E. J. Roem. & 1.41 & 0.31 & 1 & $2 x$ & 7 \\
\hline Cydonia oblonga Mill. & 1.45 & 0.14 & 1 & $2 x$ & 1 \\
\hline Mespilus germanica $\mathrm{L}$. & 1.48 & 0.15 & 1 & $2 x$ & 3 \\
\hline Eriobotrya japonica (Thunb.) Lindl. & 1.54 & 0.17 & 1 & $2 x$ & 1 \\
\hline Cotoneaster melanocarpa Lodd. & 2.24 & 0.20 & 1 & $4 x$ & 4 \\
\hline Photinea parvifolia (E. Pritz.) Schneid. & 2.29 & 0.26 & 1 & & \\
\hline Aronia arbutifolia (L.) Pers. & 2.57 & 0.20 & 1 & $2 x ; 4 x$ & 7 \\
\hline Crataegus crus-galli $\mathrm{L}$. & 2.71 & 0.24 & 1 & $3 x ; 4 x$ & 7 \\
\hline
\end{tabular}

a Source: 1 = this paper; 2 = Bennett and Smith, 1991; 3 = Arumuganathan and Earle, 1991b; 4 = Bennett, Smith, and Heslop-Harrison, 1982; $5=$ Bennett and Smith, 1976 .

b Ploidy reference: 1 = Index to plant chromosome numbers 1984-1985. (Peter Goldblatt, ed. 1988. Monographs in Systematic Botany from the Missouri Botanical Garden 23.) 2 = Index to plant chromosome numbers 1982-1983. (Peter Goldblatt, ed. 1985. Monographs in Systematic Botany from the Missouri Botanical Garden 13.) $3=$ Index to plant chromosome numbers 1972. (R. J. Moore, ed. 1974. Regnum Vegetabile 91 .) $4=$ Index to plant chromosome numbers 1967-1971. (R. J. Moore, ed. 1973. Regnum Vegetabile 90.) $5=$ Index to plant chromosome numbers 1966 . (R. Ornduff, ed. 1968. Regnum Vegetabile 55.) $6=$ Index to plant chromosome numbers 1958-1960. (1-4 and Supplement.) (M. S. Cave, ed. University of North Carolina Press, Chapel Hill, NC.) $7=$ Chromosome atlas of flowering plants. (C. D. Darlington and A. P. Wylie, 1955. George Allen and Unwin, London.) $8=$ Chromosome numbers of flowering plants. (Z. Bolkovskikh, V. Grif, T. Matejeva, and O. Zakharyeva, eds. 1969. Izdatel'stvo Nauka, Leningrad.) 
TABLE 3. Mean C-values and standard deviations of Malus species and cultivars. Samples of Malus species were collected from trees grown at the USDA-ARS Plant Genetic Resources Unit, Geneva, New York

\begin{tabular}{|c|c|c|}
\hline & $\mathrm{pg} / 2 \mathrm{C}$ & SD \\
\hline M. angustifolia (Aiton) Michaux GMAL ${ }^{\mathrm{a}}-2347$ & 1.46 & 0.08 \\
\hline M. baccata (L.) Borkh. GMAL-0434 & 1.61 & 0.30 \\
\hline M. coronaria (L.) Mill. GMAL-2906 (3x) & 2.23 & 0.07 \\
\hline M. coronaria (L.) Mill. GMAL-3064 (4x) & 3.11 & 0.13 \\
\hline M. florentina (Zuccagni) Schneid. GMAL-1546 & 1.63 & 0.23 \\
\hline M. formosana Kaw. \& Koidz. GMAL-2726 & 1.23 & 0.30 \\
\hline M. fusca (Raf.) Schneid. GMAL-1234 & 1.54 & 0.26 \\
\hline M. honanensis Rehd. GMAL-2721 & 1.33 & 0.23 \\
\hline M. hupehensis (Pamp.) Rehd. GMAL-1022 (3x) & 2.30 & 0.24 \\
\hline M. ioensis (A. Wood) Britt. GMAL-2941 & 1.55 & 0.10 \\
\hline M. kansuensis (Batal.) Schneid. GMAL- 1840 & 1.33 & 0.25 \\
\hline M. prunifolia (Willd.) Borkh. GMAL-1069 & 1.63 & 0.27 \\
\hline M. pumila Mill. GMAL-1061 & 1.67 & 0.21 \\
\hline M. sargentii Rehd. GMAL-0539 $(3 x, 4 x)$ & 1.97 & 0.23 \\
\hline M. trilobata (Labill.) Schneid. GMAL-1836 & 1.63 & 0.25 \\
\hline M. tschonskii (Maxim.) Schneid. GMAL-1834 & 1.21 & 0.24 \\
\hline M. transitoria (Batal.) Schneid. GMAL-1822 & 1.51 & 0.30 \\
\hline M. yunnanensis (Franch.) Schneid. GMAL-1819 & 1.39 & 0.16 \\
\hline \multicolumn{3}{|l|}{ M. $\times$ domestica Borkh. } \\
\hline “0523” GMAL-0523 & 1.50 & 0.29 \\
\hline "Liberty" GMAL-0824 & 1.55 & 0.21 \\
\hline "Bedford" & 1.56 & 0.25 \\
\hline "Prima" GMAL-1064 & 1.59 & 0.29 \\
\hline "Prince George" & 1.64 & 0.24 \\
\hline "Spartan" GMAL-1247 & 1.73 & 0.33 \\
\hline “Jonagold” GMAL-0619 (3x) & 2.51 & 0.20 \\
\hline "E8" (4x) & 2.86 & 0.43 \\
\hline
\end{tabular}

a GMAL refers to the catalog number for Malus at the National Germplasm Repository for Apple and Grape, Geneva, NY.

though little is known about C-value variation in many angiosperm families, five- to tenfold differences among diploids are found within other flowering plant families with up to 30 -fold ranges in 19 genera (30 species) of Iridaceae (Goldblatt, Walbot, and Zimmer, 1984), 40fold in two genera (seven species) of Droseraceae (Rothfels and Heimburger, 1968), and 80-fold in six genera (22 species) of Ranunculaceae (Rothfels et al., 1966). With the very recent publication of the extremely small C-value of Rosa wichuraiana (Bennett and Smith, 1991) (Table 2), the range of known Rosaceae C-values has been doubled. Nevertheless, compared to that of other angiosperm families, Rosaceae C-value variation is low, even including the Maloideae which is thought to be of polyploid origin.

Because 2C-value variation within the family is relatively low, we did not expect to find much variation within genera or species. 2C values of 17 diploid Malus species, including representatives from the five sections of Huckins (1972) (Table 3), ranged only from 1.21 to $1.67 \mathrm{pg}$. In contrast to this rather small range of variation, Laurie and Bennett (1985) found about twofold differences in nuclear DNA contents among diploid Zea species, while threefold differences in DNA content have been reported among diploid Microseris species (Price and Bachmann, 1975), fourfold in Helianthus and Anemone (Sims and Price, 1985; Rothfels et al., 1966), fivefold in Vicia (Raina and Narayan, 1984), and ninefold in Crepis (Jones and Brown, 1976).

$\mathrm{C}$-values of diploid $M . \times$ domestica cultivars ranged from 1.50 to $1.73 \mathrm{pg} / 2 \mathrm{C}$ (Table 3). Similarly, within sev-
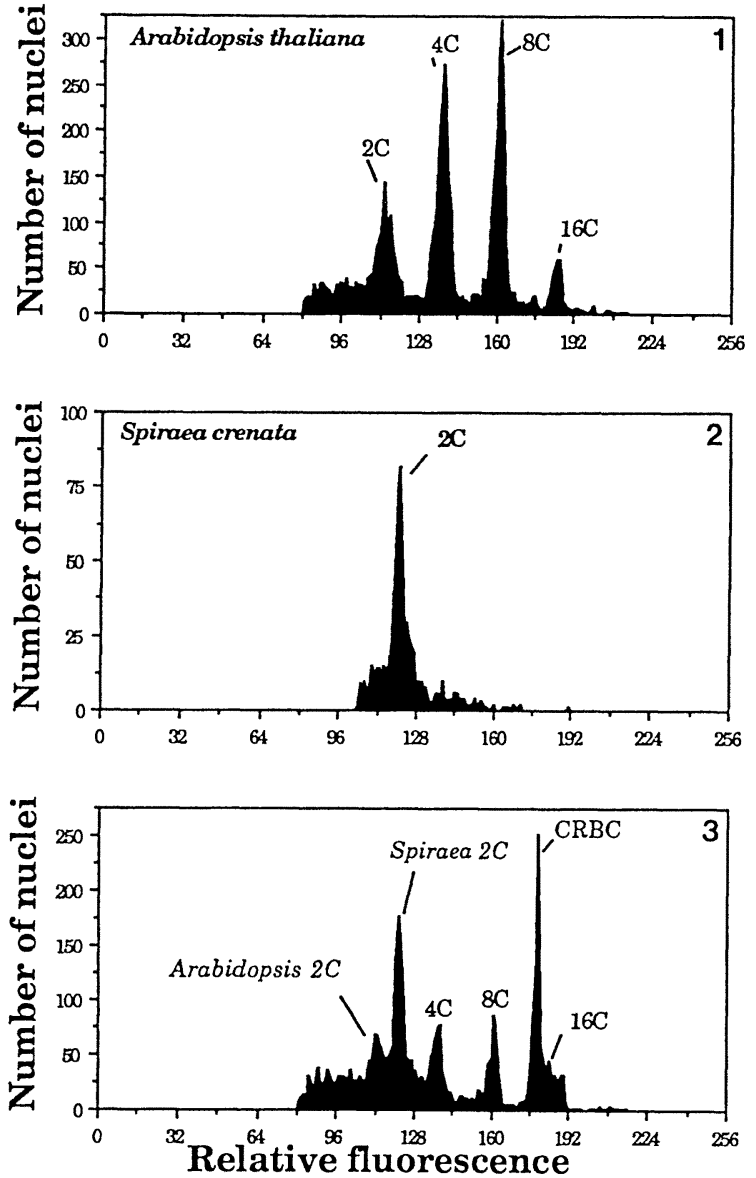

Figs. 1-3. Numbers of nuclei as a function of fluorescence intensity (log scale). 1. Arabidopsis thaliana. The multiple peaks correspond to multiple ploidy levels of nuclei within a single plant's leaves. 2. Spiraea crenata. 3. Arabidopsis thaliana, Spiraea crenata, and chicken red blood cells (CRBC) combined.

eral species of Malus (three species of Malus section Chloromeles; Dickson, unpublished data), the $2 \mathrm{C}$ variation (less than 2\%) is lower than that between species of Malus. In comparison, $\mathrm{C}$-values of inbred lines of Helianthus annuus have as much as $32 \%$ variation (Michaelson, et al., 1991b).

Evolution of the Maloideae - The relatively high chromosome number of the Maloideae $(x=17)$ suggested to early workers that the subfamily had a polyploid origin. Controversies arose, however, concerning whether 7,8 , or 9 was the progenitor chromosome base number of an autopolyploid Maloideae, and later, whether the subfamily was allopolyploid (Nebel, 1929; Tishler, 1929; Darlington and Moffett, 1930; Sax, 1931). Isozyme studies of Malus show duplicated gene systems indicative of polyploidy, and allele segregations and fixed heterozygosities suggestive of allopolyploidy (Chevreau, Lespinasse, and Gallet, 1985; Chevreau and Laurens, 1987; Weeden and Lamb, 1987; Dickson, Kresovich, and Weeden, 1991). The meiotic behavior of triploid apple convinced Sax (1932) that the Maloideae arose following hybridization between ancestors within the Rosaceae having $x=8$ and $x=9$. Stebbins (1950) argued on morphological grounds 

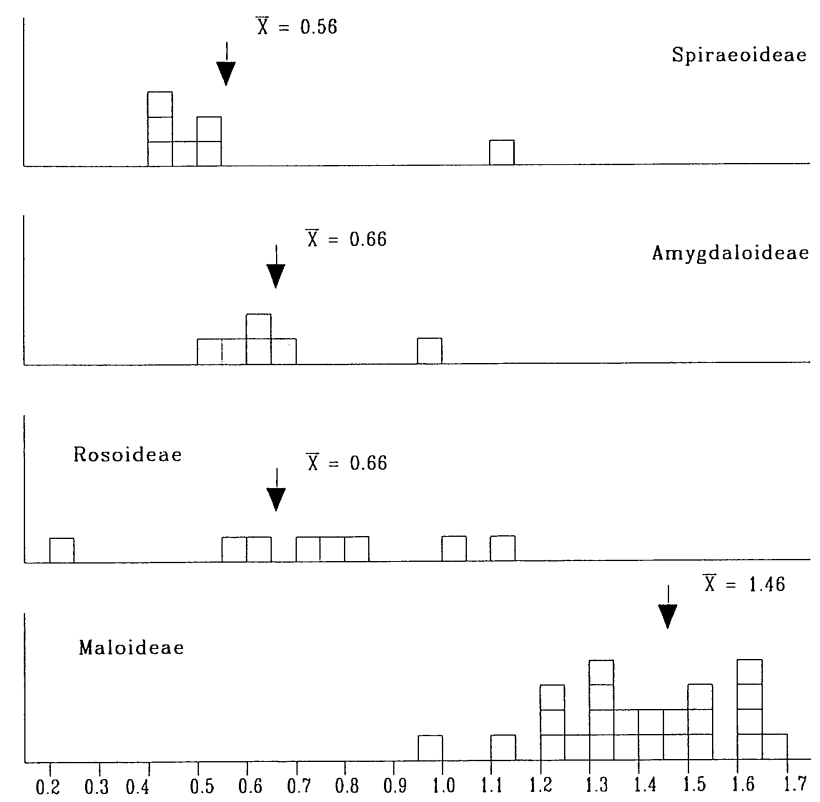

Fig. 4. Distribution and mean (arrows) $2 \mathrm{C}$-values of diploid plants of Rosaceae subfamilies (from Table 1).

that a primitive amygdaloid $(x=8)$ and a primitive spiraeoid $(x=9)$ were the likely parents. More recent morphological (Phipps et al., 1991) and chemical (Challice, 1974, 1981) data support this view.

Diploid nuclear DNA contents of the four Rosaceae subfamilies overlap in value, and subfamily $C$-value means are not correlated with chromosome numbers. However, the DNA contents within the Maloideae are broadly consistent with a polyploid origin of the subfamily (Table 1; Fig. 4). Diploid Maloideae values correspond to the sum of two diploid genomes from any of the other subfamilies that could be the result of either an autopolyploid or allopolyploid doubling of genomes. Assuming allopolyploidy, C-value data cannot resolve whether an originating hybridization occurred between genera or species within the same or from different subfamilies. Therefore, none of the other subfamilies can be excluded as possible ancestors of the Maloideae based on nuclear DNA content alone.

\section{LITERATURE CITED}

Arumuganathan, K., AND E. D. Earle. 1991a. Estimation of nuclear DNA content of plants by flow cytometry. Plant Molecular Biology Reporter 9: 229-241.

$\longrightarrow$, AND - 1991b. Nuclear DNA content of some important plant species. Molecular Biology Reporter 9: 208-218.

BENNETT, M. D., AND J. B. SMITH. 1976. Nuclear DNA amounts in angiosperms. Philosophical Transactions of the Royal Society of London B 274: 227-274.

- AND - 1991. Nuclear DNA amounts in angiosperms. Philosophical Transactions of the Royal Sociey of London B 334: 309-345.

- - , AND J. S. Heslop-HARRISON. 1982. Nuclear DNA amounts in angiosperms. Proceedings of the Royal Society of London B 216: 179-199.

Challice, J. S. 1974. Rosaceae chemotaxonomy and the origins of the Pomoideae. Journal of the Linnean Society of London, Botany 69: 239-259.

- 1981. Chemotaxonomic studies in the family Rosaceae and the evolutionary origins of the subfamily Maloideae. Preslia 53: 289-304.

Chevreau, E., AND F. Laurens. 1987. The pattern of inheritance in apple (Malus $\times$ domestica Borkh.): further results from leaf isozyme analysis. Theoretical and Applied Genetics 75: 90-95.

- Y. LespinASSE, AND M. Gallet. 1985. Inheritance of pollen enzymes and polyploid origin of apple. Theoretical and Applied Genetics 71: 268-277.

CноoI, W. Y. 1971. Variation in nuclear DNA content in the genus Vicia. Genetics 68: 195-211.

Darlington, C. D., AND A. A. MoffetT. 1930. Primary and secondary chromosome balance in Pyrus. Journal of Genetics 22: 129-151.

- AND A. P. WYLIE. 1955. Chromosome atlas of flowering plants, $2 \mathrm{~d}$ ed. George Allen and Unwin, London.

De LaAt, A. M., W. Gohde, and M. J. D. C. Vogelzang. 1987. Determination of ploidy of single plants and plant populations by flow cytometry. Plant Breeding 99: 303-307.

Dickson, E. E., S. Kresovich, AND N. F. WeEDEN. 1991. Isozymes in North American Malus (Rosaceae): hybridization and species differentiation. Systematic Botany 16: 363-375.

Galbraith, D. W., K. R. Harkins, and S. KNAPP. 1991. Systematic endopolyploidy in Arabidopsis thaliana. Plant Physiology 96: 985989.

$\longrightarrow,-$ J. M. Maddox, N. M. Ayres, D. P. Sharma, and E. FIROOZABODY. 1983. Rapid flow cytometric analysis of the cell cycle in intact plant tissues. Science 220: 1049-1051.

Goldblat, P., V. WAlbot, AND E. A. Zimmer. 1984. Estimation of genome size (C-value) in Iridaceae by cytophotometry. Annals of the Missouri Botanical Garden 71: 176-180.

HuCKINS, C. A. 1972. A revision of the sections of the genus Malus Miller. Ph.D. dissertation, Cornell University. Ithaca, NY.

JONES, R. N., AND L. M. BRown. 1976. Chromosome evolution and DNA variation in Crepis. Heredity 36: 91-104.

LAURIE, D., AND M. D. BENNETT. 1985. Nuclear DNA content in the genera Zea and Sorghum. Intergeneric, interspecific and intraspecific variation. Heredity 55: 307-313.

Leutwiler, L. S., B. R. Hough-Evans, ANd E. M. Meyerowitz. 1984. The DNA of Arabidopsis thaliana. Molecular and General Genetics 194: 15-23.

MCMURPHY, L. M., AND A. L. RAYBURN. 1991. Lack of relationship between relative maturity and genome size in hybrid maize. Crop Science 31: 63-67.

Michaelson, M. J., H. J. Price, J. R. Ellison, and J. S. Spencer. 1991a. Comparison of plant DNA contents determined by Feulgen microspectrophotometry and laser flow cytometry. American Journal of Botany 78: 183-188.

,$- \longrightarrow$, J. S. JohnSTON, AND J. R. Ellison. 1991b. Variation of nuclear DNA content in Helianthus annuus (Asteraceae). American Journal of Botany 78: 1238-1243.

NARAYAN, R. K. J. 1982 . Discontinuous DNA variation in the evolution of plant species: the genus Lathyrus. Evolution 36: 877-891.

Nebel, B. 1929. Zur cytologie von Malus II. Zuchter 1: 215-217.

OHRI, D., AND T. N. KHOSHOo. 1986. Plant DNA: contents and systematics. In S. K. Dutta [ed.], DNA systematics, vol. 2: Plants, 119. CRC Press, Boca Raton, FL.

Phipps, J. B., K. R. Robertson, J. R. Rohrer, AND P. G. SMith. 1991. Origins and evolution of subfam. Maloideae (Rosaceae). Systematic Botany 16: 303-332.

Price, H. J. 1988. Nuclear DNA content variation within angiosperm species. Evolutionary Trends in Plants 2: 53-60.

, AND K. BACHMANN. 1975. DNA content and evolution in the Microseridinae. American Journal of Botany 62: 262-267.

, K. L. Chambers, K. Bachmann, AND J. Riggs. 1983. Inheritance of nuclear 2C DNA content variation in intraspecific and interspecific hybrids of Microseris (Asteraceae). American Journal of Botany 70: 1133-1138.

RAINA, S., AND R. K. NARAYAN. 1984. Changes in DNA composition in the evolution of Vicia species. Theoretical and Applied Genetics 68: 187-192.

RAYBURN, A. L. 1990. Genome size variation in southwestern United States Indian maize adapted to various altitudes. Evolutionary Trends in Plants 4: 53-57.

, J. A. Auger, E. A. Benzinger, And A. G. Hepburn. 1989. 
Detection of intraspecific DNA content variation in Zea mays ssp. mays by flow cytometry. Experimental Botany 40: 1179-1183.

RoBERTSON, K. R. 1974. The genera of the Rosaceae in the southeastern United States. Journal of the Arnold Arboretum 55: 303-662.

Rothfels, K., AND M. Heimburger. 1968. Chromosome size and DNA values in sundews (Droseraceae). Chromosoma 25: 96-103. -, E. Sexsmith, M. Heimburger, AND M. Krause. 1966. Chromosome size and DNA content of species of Anemone L. and related genera (Ranunculaceae). Chromosoma 20: 54-74.

SAX, K. 1931. The origin and relationships of the Pomoideae. Journal of the Arnold Arboretum 12: 3-22.

. 1932. The origin of the Pomoideae. Proceedings of the American Horticultural Society 30: 147-150.
Sims, L., AND H. J. Price. 1985. Nuclear DNA content variation in Helianthus (Asteraceae). American Journal of Botany 72: 12131219.

SteBbiNs, G. L. 1950. Variation and evolution in flowering plants. Columbia University Press, New York, NY.

TishleR, G. 1929. Verknupfungsversuche von Zytologie und Systematik bei den Blutenpflanzen. Berichte der Deutschen Botanischen Gesellschaft 47: 30-49.

WeEDEN, N. F., AND R. C. LAMB. 1987. Genetics and linkage analysis of 19 isozyme loci in apple. Journal of the American Society of Horticultural Science 112: 865-872.

\section{ERRATUM}

The cover photograph on the June 1992 American Journal of Botany was printed upside down. The species listed for top and bottom rows should be reversed in the caption for the cover illustration at the top of the Contents page in that issue. 